\title{
Index to volume 106
}

Alexander, M., see Grant et al.

Atchue III, J. A., Day, Jr., F. P. \& Marshall, H. G.: Algal dynamics and nitrogen and phosphorus cycling in a cypress stand in the seasonally flooded Great Dismal Swamp

Bergstein, T. \& Cavari, B. Z.: Sulfide utilization by the photosynthetic bacterium Chlorobium phaeobacteroides

Bluzat, R., see Seugé \& Bluzat

Bongers, T.: Orthophallonema; A new genus for Leptosomatum ranjhai Timm, 1960

Burrows, I. G. \& Whitton, B. A.: Heavy metals in water, sediments, and invertebrates from a metalcontaminated river free of organic pollution

Carpenter, J. W., Green, R. H. \& Paterson, C. G.: A preliminary organic carbon budget for a small dystrophic lake in Maritime Canada

Caumette, P., Pagano, M.\& Saint-Jean, L.: Répartition verticale du phytoplancton des bactéries et du zooplancton dans un milieu stratifié en Baie de Biétri (Lagune Ebrié, Cote d'Ivoire). Relations trophiques

Cavari, B. Z., see Bergstein \& Cavari

Chessel, D., see Gaschignard et al.

Christopher, M. S. M., see Marian et al.

Crivelli, A. J.: The destruction of aquatic vegetatio by carp: A comparison between Southern France and the United States

Day, Jr., F. P., see Atchue et al.

De Deckker, P.: Notes on the ecology and distribution of non-marine ostracods in Australia

Dumont, H. J.: Discovery of groundwater-inhabiting Chydoridae (Crustacea: Cladocera), with the description of two new species

Eaton, K. A.: The life history and production of Chaoborus punctipennis (Diptera: Chaoboridae) in Lake Norman, North Carolina, U.S.A.

Eddy, F. B. \& Maloiy, G. M. O.: Sodium balance in the catfish Clarias mossambicus exposed to acid water

Egan, E. A., see Grant et al.

Einsle, U.: Long-term changes in planktonic associations of crustaceans in Lake Constance and adjacent waters and their effects on competitive situations

Erséus, C.: New records of Adelodrilus (Oligochaeta, Tubificidae), with descriptions of two new species from the North-west Atlantic

Frey, D. G., see Michael \& Frey

Gaschignard, O., Persat, H. \& Chessel, D.: Répartition transversale des macroinvertébrés benthiques dans un bras du Rhône

Grant, I. F., Egan, E. A. \& Alexander, M.: Measurement of rates of grazing of the ostracod Cyprinotus carolinensis on blue-green algae

Green, R. H., see Carpenter et al. 
Jordan, R. A., Martin, P. G. \& Sutton, C. E.: Selective effects of phytoplankton entrainment at the Surry Power Plant, James River, Virginia

Korhonen, K., see Niemi et al.

Kuparinen, J., see Niemi et al.

Madsen, H., Thiongo, F. W. \& Ouma, J. H.: Egg laying and growth in Helisoma duryi (Wetherby) (Pulmonata: Planorbidae): Effect of population density and mode of fertilization

Maloiy, G. M. O., see Eddy \& Maloiy

Marian, M. P., Christopher, M. S. M., Selvaraj, A. M. \& Pandian, T. J.: Studies on predation of the mosquito Culex fatigans by Rana tigrina tadpoles

Marshall, H. G., see Atchue et al.

Martin, P. G., see Jordan et al.

Maughan, O. E., see Orth \& Maughan

Michael, R. G. \& Frey, D. G.: Assumed Amphi-Atlantic distribution of Oxyurella tenuicaudis (Cladocera, Chydoridae) denied by a new species from North America

Milbrink, G.: Characteristic deformities in tubificid oligochaetes inhabiting polluted bays of Lake Vänern, Southern Sweden

Niemi, M., Kuparinen, J., Uusi-Rauva, A. \& Korhonen, K.: Preparation of ${ }^{14} \mathrm{C}$-labeled algal samples for liquid scintillation counting

Nogrady, T.: Some new and rare warmwater rotifers

Nriagu, J. O.: Rapid decomposition of fish bones in Lake Erie sediments

Orth, D. J. \& Maughan, O. E.: Microhabitat preferences of benthic fauna in a woodland stream

Ouma, J. H., see Madsen et al.

Pagano, M., see Caumette et al.

Pandian, T. J., see Marian et al.

Paterson, C. G., see Carpenter et al.

Persat, H., see Gaschignard et al.

Reddy, P. M: Effects of temperature pre-treatment, desiccation and aging on the viability of halophilic blue-green algae

Saint-Jean, L., see Caumette et al.

Schmitz, E. H., see Schram \& Schmitz

Schram, M. D. \& Schmitz, E. H.: Correlation of total organic carbon and dry weight data as indices of fresh-water zooplankton biomass

Selvaraj, A. M., see Marian et al.

Seugé, J. \& Bluzat, R.: Chronic toxicity of three insecticides (carbaryl, fenthion and lindane) in the freshwater snail Lymnaea stagnalis

Simola, H.: Limnological effects of peatland drainage and fertilization as reflected in the varved sediment of a deep lake

Sutton, C. E., see Jordan et al.

Thiongo, F. W., see Madsen et al.

Uusi-Rauva, A., see Niemi et al.

Whitton, B. A., see Burrows \& Whitton 